\title{
Efektivitas Penggunaan Model Quantum Teachingdalam Meningkatkan Hasil Belajar IPA
}

\author{
Alice YeniVerawatiWote \\ Pendidikan Guru Sekolah Dasar, Fakultas Keguruan dan Ilmu Pendidikan,Universitas Halmahera, Indonesia \\ Email: alicewote23@gmail.com \\ MardinceSasingan \\ Pendidikan Guru Sekolah Dasar, Fakultas Keguruan dan Ilmu Pendidikan, Universitas Halmahera, Indonesia \\ Email: mardincesasingan88@gmail.com \\ OkvinElselrisKitong \\ Pendidikan Guru Sekolah Dasar, Fakultas Keguruan dan Ilmu Pendidikan,Universitas Halmahera, Indonesia \\ Email: okvinkitong@gmail.com
}

\author{
A R T I C L E I N F O \\ Article history: \\ 1 Maret 2020 Received in \\ revised form \\ 30 Maret 2020 \\ Accepted 11 April 2020 \\ Available online 15 \\ Mei 2020 \\ Kata Kunci: \\ Quantum Teaching, IPA \\ Hasil Belajar \\ Keywords: \\ Quantum Teaching, Natural \\ Sciences, Learning Outcomes
}

\begin{abstract}
A B S T R A K
Penelitian ini bertujuan untuk mengetahui perbedaan positif signifikan dalam penerapan model pembelajaran quantum teaching pada hasil belajar mata pelajaran IPA siswa kelas IV.Penelitian ini dilaksanakan di kelas IV SD INPRES Kupa-Kupa dengan populasi 20 orang siswa. Sampel dari penelitian ini adalah siswa kelas IV yang dibagi dua kelompok yaitu sebagai kelompok kontrol berjumlah 10 orang siswa dan kelompok eksperimen 10 orang siswa dalam menerapkan model pembelajaran Quantum Teaching. Penelitian ini menggunakan rancangan desain post-test only. Instrumen yang digunakan adalah tes berupa hasil post test yang diberikan kepada siswa dari dua kelompok. Analisis data menggunakan uji normalitas, homogenitas dan hipotesis. Ujihipotesis yang dilkukanmengunakanuji-t. Hasil penelitian menunjukan perbedaan rata-rata diperoleh nilai post-test kelompok eksperimen yaitu 87 lebih tinggi dibandingkan kelompok kontrol dengan nilai post-test 52. Sedangkan thitung $=14.42>t_{\text {tabel }}=2.228$ maka dapat disimpulkan $\mathrm{HO}$ ditolak dan $\mathrm{Ha}$ diterima atau penerapan model pembelajaran quantum teaching dapat meningkatkan hasil belajar IPA kelas IV SD INPRES Kupa-Kupa. Model quantum teachingmemberikan kesempatan bagi guru untuk menginovasi pembelajarannya, sehingga pembelajaran menyenangkan terwujud serta nantinya akan berdampak terhadap hasil belajar siswa.
\end{abstract}

\begin{abstract}
A B S T R A C T
The aim of this research was to determine the significant difference in the application of quantum teaching learning model in natural science subject. This research was conducted on fourth grade students of SD INPRES Kupa-Kupa with the population of 20 students. The sample of this research divided into control group consisted of 10 students and the experimental group consisted of 10 students. This research used a post-test only design. Data analysis used normality, homogeneity and hypothesis test. The result showed that the average score obtained by post test of experimental group, it was 87 higher than control group, it was 52. The t-count $=14.42>t$-table $=2.228$, it could be concluded that HO was rejected and Ha was accepted or the application of a quantum teaching learning model could improve the learning outcomes on fourth grade elementary students.
\end{abstract}

\section{Pendahuluan}

Pembelajaran adalah sebuah proses interaksi antara peserta didik serta sumber belajar. Dalam proses pembelajaran interaksi yang baik harus terjadi dari segala arah. Dalam proses pembelajaran orang dewasa akan membimbing, melatih siswa sehingga tujuan pembelajaran itu tercapai yaitu tujuan pengetahuan, perubahan sikap serta menguasai keterampilan yang nantinya bisa dipergunakan dengan baik. Menurut Corey (Sagala, 2011) pembelajaran adalah proses dimanaseseorangsecarasegajamembuat program yang menghasilkan sebuah respon atau perubahan tingkah laku tertentu terhadap situasi yang diprogramkan. Proses pembelajaran idealnya adalah proses mengaktifkan siswa untuk menemukan pengetahuannya sendiri serta mengelolanya sendiri, pengajar hanya berperan sebagaifasillitatorsertapenyediasumber belajar. Dengan proses pembelajaran yang seperti itu memungkinkan siswa mempunyai pengalaman yang akan diingat dalam jangka waktu yang panjang. Hal ini senada dengan pendapat yang di jabarkan oleh Sari (2013) yaitu pengetahuan akan dibentuk apabila anak mengalami interaksi dengan lingkungan, informasi tidak secara sengaja dituangkan melainkan ditemukan dikelola sendiri. 
Di sekolah dasar salah satu mata pelajaran yang dipelajari adalah pelajaran IPA. Pelajaran IPA adalah salah satu pelajaran yang mempelajari gejala alam melalui proses ilmiah yang dilalui anak, yang sesuai dengan prosedur yang jelas (Susanto, 2013). SedangkanmenurutWahyanadalam Trianto (2010) menyatakan bahwa pembelajaran IPA adalah kumpulan interdisiplin ilmu yang tersusun secarasistematis serta penggunaannya secara umum terbatas pada gejala-gejala alam. Pembelajaran IPA bertujuan untuk mengembangkan pengetahuan serta mengembangkan daya berfikir kritis anak. Sedangkanmenurut Samatowa (2010) IPA adalahilmu yang pembahasannya tentang gejala alam yang disusun secara sitematis yang didasarkan pada proses ilmiah. Jadi dapat dikatakan bahwa pelajaran IPA adalah pelajaran yang mempelajari gejala alam yang disusun secara sistematis yang dimana prosesnya melalui kajian Ilmiah.Pelajaran IPA dapat mengembangkan kemampuan berfikir kritis dan salah satu tujuan pembelajaran IPA di SD adalah mengembangkan pengetahuan dan pemahaman konsep-konsep IPA yang bermanfaat dan dapat diterapkan dalam kehidupan sehari-hari. Keberhasilan belajar pada setiap jenjang sekolah dipengaruhi oleh beberapa faktor. Faktor yang mempengaruhi belajar siswa ada dua macam yaitu faktor internal dan eksternal. Faktor internal berasal dari dalam diri siswa sendiri, meliputi intelegensi, minat, motivasi, kesehatan dan cara belajar, sedangkan faktor eksternal berasal dari luar diri siswa meliputi lingkungan keluarga, sekolah danmasyarakat (Sugihartono, 2007). Jadi, dapat dikatakan bahwa proses pembelajaran akan berlangsung dengan baik tidak bisa terlepas dari peran guru, dalam merancang pembelajaran. Pemilihan model serta mendesain pembelajaran yang menarik sangatlah berdampak terhadap proses pembelajaran. Guru hendaknya menyajikan materi dengan model dan metode yang bervariasi dengan dibantu media yang tepat sehingga pembelajaran menjadi menarik dan tidak membosankan. Pembelajaran yang berhasil dapat diukur dari nilai yang diperoleh dari perubahan tingkah laku yang dapatdilihat (Kasmadi, 2001).

Masalah baru muncul saat proses pembelajaran yang harusnya berpusat kepada siswa menjadi berpusat kepada guru, dengan kata siswa tidak aktif dalam proses pembelajaran serta guru yang aktif serta menuangkan semua pengetahuan yang diamiliki kepada siswanya. Hal ini akan berdampak terhadap hasil belajar siswa. Masalah lain adalah dalam proses pembelajaran yang dilakukan guru menggunakan model konvensional yang berdampak terhadap proses pembelajaran. Pernyataan ini sesuai dengan hasil observasi yang dilakukan yaitu perencanaan pembelajaran IPA di SD telah diupayakan agar mencapai tujuan yang diharapkan, namun kenyataan menunjukkan bahwa masih dijumpai kekurangan dalam proses pengajarannya, termasuk masalah di kelas IV SD INPRES KupaKupa dalam pembelajaran IPA. Hasil belajar yang diperoleh siswa pada materi tersebut masih tergolong rendah,sehingga dapat berpengaruh terhadap hasil belajar siswa. Guru sudah melakukan usaha perbaikan dalam proses pembelajaran dengan menerapkan metode pembelajaran yang menarik seperti metode ceramah dan penugasan. Namun, dari usaha yang telah dilakukan oleh guru dan pihak sekolah, menunjukkan hasil belajar masih belum maksimal.Hal tersebut terlihat dari sikap belajar siswa yang masih cenderung pasif pada saat pembelajaran IPA berlangsung. Sikap tersebut kemungkinan dapat disebabkan karena dalam proses pembelajaran guru lebih banyak menjelaskan dibandingkan dengan melibatkan siswa secara langsung, sehingga pembelajaran masih berpusat pada guru (teacher centered). Siswa belum diberikan kesempatan untuk terlibat dalam pemahaman konsep IPA, masih banyak siswa yang belum memahami materi yang baru saja mereka pelajari saat evaluasi pembelajaran dilaksanakan. Jadi dapat dikatakan bahwa proses pembelajaran sangat dipengaruhi denganpemilihan model pembelajaran yang digunakandalam merancang proses pembelajaran. Salah satu model pembelajaran yang menyenangkan dan dapat meningkatkan hasil belajar siswa adalah Model Quantum Teaching.

Menurut Wena (2013) model quantum teaching adalah cara baru dalam proses belajar yang memadukan yang memadukan unsur seni dan tujuan pembelajaran mata pelajaran dengan menggabungkan keistimewaankeistimewaan belajar menuju bentuk perencanaan pengajaran yang akan meningkatkan hasil belajar siswa. Model pembelajaran quantum teaching merupakan model percepatan belajar (accelerated learning) yangmembiasakan belajar nyaman dan menyenangkan. Model quantum teaching memiliki rumusan pembelajaran yang menjadi langkah-langkah dalam prosespembelajaran. Rumusan tersebut dikenal dengan rumusan Tumbuhkan,Alami, Namai, Demonstrasikan, Ulangi dan Rayakan (TANDUR). Denganditerapkannya tiap langkah model quantum teaching dengan baik maka siswaakan dilibatkan secara aktif dalam kegiatan pembelajaran. Selain itu siswajuga akan belajar dalam suasana yang meriah dan menyenangkan sehingga siswa tidak akan mudah merasa jenuh selama kegiatan pembelajaran berlangsung. Dengan upaya tersebut maka diharapkan hasil belajar siswaakan mengalami peningkatan sesuai dengan indikator capaian penelitian yangtelah ditentukan. DePorter, dkk. (2014) Model quantum teaching mempunyai beberapa kelebihan yaitu: 1) dapat membimbing dan mengarahkan cara berpikir siswa; 2) berpusat terhadap apa yang dialami oleh siswa dalam proses belajarnya; 3) menumbuhkan dan menimbulkan keinginan siswa untuk belajar; 4) menciptakan rasa kerja sama antar siswa;5) menawarkan proses pembelajaran yang menyenangkan dan mudah dipahami siswa; 6) menciptakan rasa percaya diri siswa;7) menciptakan pembelajaran yang menyenangkan; 8) memotivasi siswa untuk terus berkembang; 9) siswa bebas berekspresi; 10) menumbuhkan rasa idealism, gairah dan cinta mengajar pada guru (Suryanti \& Yunianta, 2018). Melihat kelebihan dari model Quantum teachingbanyakpenelian yang sudahdilakukan. 
Beberapa penelitian yang sudah dilakukan antara lain Cahyaningrum, Yahya, \& Asyhari (2019) yang menyatakan bahwa model quantum teaching tipe Tandur dapat meningkatkan hasil belajar siswa. Pendapat Fauzi \& Noviartati (2018) menyatakan bahwa model quatum teaching tipe Tandur dapat meningkatkan motivasi belajar siswa. Pendapat yang samadiajukanoleh Yahya (2017) model pembelajaran quatum TeachingtipeTandur dapat meningkatkan hasil belajar Biologi siswa. Hasil penelitian serupa disampaikan oleh Rohimah, Suprapta, \& Agung (2019) yang menyatakan bahwa model Quantum teaching Tipe Tandur dapat menumbuhkan pengetahuannya sendiri serta dapat mengeksplorasi materi dengan kehidupannya sehari-hari sehingga pelajaran menjadi lebih menarik. Dari pejabaran hasil penelitian yang sudah dilakasankan serta kelebihan model quatum teaching dapat meningkatkan hasil belajar siswa serta dengan penerapan model ini akan menjawab atau dengan kata lain dapat memberi solusi terkait masalah yang dijabarkan sebelumnya. Tujuan dari penelitian ini adalah untuk mengetahui apakah terdapat perbedaan positif signifikan model pembelajaran quantum teaching pada hasil belajar mata pelajaran IPA Siswa Kelas IV SD InpresKupa-KupaKecamatanTobelo Selatan.

\section{Metode}

Jenis penelitain yang dilakukan adalah pre-eksperiment dengan rancangan desain penelitian yaitu menggunakan Post Test only Design. Penelitian ini mempunyai dau variabel yaitu variabel bebas adalah penggunaan model Quantum teaching tipe Tandur sedangkan variable terikatnya adalah hasil belajar IPA. Populasi kelas IV SD INPRES Kupa-Kupa dengan Jumlah20 orang siswa. Sampel dari penelitian ini adalah siswa kelas IV yang dibagi dua kelompok yaitu sebagai kelompok kontrol berjumlah 10 orang siswa dan kelompok eksperimen 10 orang siswa dalam menerapkan model pembelajaran Quantum Teaching. Dalam pelaksanaan penelitian ini akan dilakukan tiga prosedur yaitu 1) proses perencanaan dilakukan dengan merancang RPP yang sesuai dengan langkah-langkah pembelajaran menggunakan model quantum Teachin. 2) tahap pelaksanakan dilaksanakan yaitu melaksanakan proses pembelajaran yang dirancang dalam proses rancangan serta mengamati sertamelakukanujipotstest. 3) tahap menganalisi data hasilbelajar IPA. Teknik pengumpulan data yang dilakukan menggunakan tes yang mana sebelum digunakan terlebih dahulu dilakukan uji intrumen dengan mengukur validitas, reliabilitas, daya beda dan tingkat kesukaran soal. Setelah melalui hal tersebut maka soal akan diberikan pada saat posttest. Adapun teknik analisis data yang digunakan yaitu analisis statistik deskriptif dan analisis statistik inferensial. Pada teknik analisis dengan statistik deskriptif akan mengukur median, modus, mean, nilai maksimum, serta nilai minimal. Sedangkan dalam uji inferensial dilakukan dua uji yaitu uji prasyarat dan uji hipotesis. Dalam uji prayarat perhitungan yang dilakukan adalah ujinormalitas serta uji homogenitas. Uji ini dilakukan untuk mengetahuai apakah data bisa dilakukan dengan uji hipotesis. Setelah data normal serta homogen maka akan dilakukan uji selanjutnya yaitu uji hipotesis dengan uji t-test.

\section{Hasil dan Pembahasan}

Penelitianinidilaksankan di SD INPRES Kupa-Kupa pada kelas V dengan jumlah 20 orang. Pada penelitian ini mengukur hasil belajar IPA dengan alat ukur berupa tes yang diberikan pada saat akhir proses pembelajaran. Penelitian ini menguji coba penggunaan model quantum teachingyang dilaksankan di kelas eksperimen sedangkan model yang bukan model quntum teaching dikelas kontrol. Setelah diberikan perlakukan yang berbeda maka dapat diperoleh data hasi penelitian serta dianalisis secara deskriptif dan Inferesial. Data hasil uji deskriptif disajikan pada Tabel 1 dibawah ini.

Tabel 1. Data Hasil

\begin{tabular}{lcc}
\hline Analisis & \multicolumn{2}{c}{ Data Hasil Post-Test } \\
& Kelompok Eksperimen & Kelompok Kontrol \\
\hline Banyaknya Data (n) & 10 & 10 \\
Minimum & 60 & 20 \\
Maximum & 100 & 80 \\
Median & 90 & 40 \\
Modus & 90 & 40 \\
Mean & 87 & 52 \\
\hline
\end{tabular}

Berdasarkan analisis pada tabel 1 , diperoleh rata-rata nilai post-test siswa kelompok eksperimen $=87$ lebih tinggi dibandingkan nilai post-test siswa kontrol $=52$. Maka dapat disimpulkan bahwa terdapat peningkatan penerapan model quantum siswa Kelas VI SD Inpres Kupa-Kupa sebesar $87 \%$.

Selanjutnya peneliti melakukan uji prasyarat yakni ujinormalitas, homogenitas dan uji hipotesis data. Hasil uji tersebut dapat disajikan pada tabel 2 adalah sebagai berikut. 
Tabel 2. UjiNormalitas

\begin{tabular}{llll}
\hline Kelompok & Taraf Signifikansi & Keputusan \\
\hline Eksperimen & 0,258 & 0.05 & Normal \\
Kontrol & 0,1997 & 0.05 & Normal \\
\hline
\end{tabular}

Berdasarkantabel di atas dapat disimpulkan bahwa data hasil post-testkelompok eksperimen dan kelompok kontrol berdistribusi normal ataumenerima Ha (nilaiAsymp sig $>\alpha$ ).

Uji homogenitas varians yang dilakukan dalam penelitian ini menggunakan metode varian terbesar dibandingkan varian terkecil dapat dilihat pada tabel 3 , yaitusebagaiberikut:

$\mathrm{H}_{\mathrm{o}} \quad: s_{1}^{2}=s_{2}^{2}$ (varian homogen)

$\mathrm{H}_{\mathrm{a}} \quad: s_{1}^{2} \neq s_{2}^{2}$ (varian tidak homogen)

Keputusan uji jika $F_{\text {hitung }}<F_{\text {tabel }}$ maka homogen, sedangkan jika $F_{\text {hitung }}>F_{\text {tabel }}$ maka tidak homogen.

Tabel 3. Uji Homogenitas

\begin{tabular}{|c|c|c|}
\hline \multirow[t]{2}{*}{ Analisis } & \multicolumn{2}{|c|}{ Kelompok } \\
\hline & Eksperimen & Kontrol \\
\hline Rata-rata & 87 & 52 \\
\hline Varian & 17.888 & 3.511 \\
\hline $\mathrm{N}$ & 10 & 10 \\
\hline$F_{\text {hitung }}$ & 5.094 & \\
\hline $\mathrm{F}_{\text {tabel }}$ & 5.59 & \\
\hline
\end{tabular}

Berdasarkan hasil perhitungan diperoleh $F_{\max }$ atau $F_{\text {hitung }}=5,094$ pada taraf signifikansi 5\% dengan varian $=17,888$ dan db penyebut $=3,511$ diperoleh $F_{\text {tabel }}=5,59$. Oleh karena $F_{\max }<F_{\text {tabel }}$ maka dapat disimpulkan bahwa kedua kelompok tersebut homogen.

Setelah hasil analisis berupa uji normalitas dan uji homogenitas dilaksanakan serta diperoleh hasil yang sesuai dengan syarat dimana dari uji normalitas data diketahuai normal serta homogeny maka uji hipotesis dengan uji t dapat dilaksanakan. Kriteria pengujian: ditolak H0 jikat $t_{\text {hitung }}=\mathrm{t}_{\text {tabel }}$ diterima $\mathrm{Ha}$ jikat $\mathrm{t}_{\text {hitung }}>\mathrm{t}_{\text {tabel }}$. Hasil uji hipotesis dengan uji-t dijabarkan sebagai berikut: Berdasarkan hasil analisis menggunakan t-Test

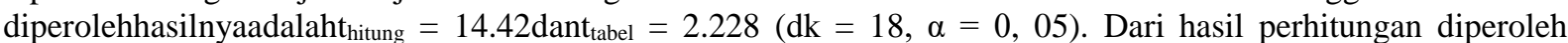
nilai $_{\text {hitung }}=14.42>\mathrm{t}_{\text {tabel }}=2.228$. Maka $\mathrm{H} 0$ ditolak atau Ha diterima, yang berarti penerapan model quantum dapat meningkatkan hasil belajar IPAsiswakelasVI SD Inpres Kupa-Kupa.

Berdasarkan analisis dapat dikatakan bahwa penerapan model pembelajaran quantum dapat meningkatkan hasil belajar IPA siswa kelas IV SD Inpres Kupa-Kupa. Pembelajaran Quantum teaching sebagai model pembelajaran, dapat dilihat dengan jelas bahwa nilai IPA siswa lebih baik dibandingkan dengan nilai siswa yang diajar dengan model pembelajaran ceramah.Diperoleh rata-rata nilaipost-test siswakelompok eksperimen = 87lebih tinggi dibandingkan nilai post-testsiswa kontrol $=52$. Kemudian mengacu pada hasil pengolahan data penelitian menggunakan uji t-test, dapat diambil kesimpulan bahwa model pembelajaran Quantum teaching efektif dalam meningkatkan hasil belajar siswa. Hal ini dapatdilihat dari hasil pengujian yang menunjukan

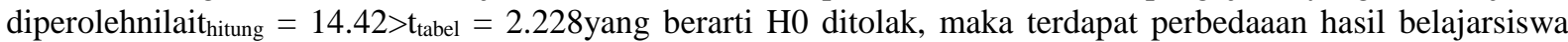
menggunakan model pembelajaran Quantum learning. Hal dilihat dengan jelas bahwa nilai IPA siswa lebih baik dibandingkan dengan nilai siswa yang diajar dengan model pembelajaran ceramah.Diperoleh rata-rata nilaiposttest siswakelompok eksperimen $=87$ lebih tinggi dibandingkan nilaipost-testsiswa kontrol $=52$.

Peningkatan hasil belajar menggunakan model pembelajaran quantum teaching disebabkan karena siswa berpartisipasi aktif dalam kegiatanpembelajaran melalui penataan lingkungan belajar, umpan balik dari sikap yangdiberikan guru, dan penerimaan siswa terhadap perlakuan yang diberikan guru selama pembelajaran berlangsung. Siswa merasakan hal baru dalam proses belajar, hal baru tersebut sangat terasa dalam penerapan aspek-aspek dari model pembelajaran quantum teaching. Peningkatan hasil belajar ini disebabkan karena materi yang disampaikan oleh guru dapat diterima oleh siswa dengan baik. Hal ini sedana dengan pendapat dari Sagala, 2008 dalam Yanuarti \& Sobandi (2016) model quatum teaching adalah model yang menggunakan pendekatan sugestology yang mana pendekatan ini akan mempengaruhi hasil belajar. Menurut Fathurrahman (2015), quantum teaching dengan tahapan TANDUR adalah model pembelajaran dikembangkan dari quantum learning yang mana pembelajaran membiasakan belajar nyaman dan menyenangkan, berusaha memberikan petunjuk dalam 
meningkatkan pemahaman dan daya ingat siswa. Model quantum teaching menciptakan pembelajaran yang efektif dan efisien adalah dengan memilih model pembelajaran yang sesuai dengan materi ajar, kemampuan dan kebutuhan siswa serta dapat menciptakan suasana pembelajaran yang menyenangkan (Isnaini et al., 2016). Rachmawati (2012) menyatakanbahwa model quatumteaching terdiridari atas dua unsur konteks dan isi. Unsur konteks terdiri atas suasana dalam proses pembelajaran baik suasan hati, sauasanalingkungan, sarana prasarana yang diatur dalam proses pembelajaran. Sedangkan kategori isi merupakan keterampilan guru dalam menyampaikan kurikulum, dan merancang pembelajaran dengan model yang akan dilakukan oleh siswa (Riyanto, 2012; dan Yaseer, Sukestiyarno, \& Masrukan, 2014).

Hal tersebut menjadi alasan model ini bisa berjalan dengan baik untuk meningkatkan hasil belajar. Karena model inimemenuhi faktor-faktor ketercapaian hasil belajar yaitu: 1) siswa dengan suasana kelas yang berbeda. 2) Siswa terbiasa belajar dengan suasana kelas yang sama setiap hari, dalam kelas teori jarang sekali siswa melakukan rotasi tempat duduk atau penataan tata letak meja yang berbeda dari biasanya untuk mengatasi kebosanan. 3) Penataanlingkungan yang dilakukan dengan baik, akan menjadi sarana yang bernilai dalam membangun dan mempertahankan sikap positif (DePorter \& Hernacki, 2000), dengan mengatur lingkungan belajar akan membuat siswa bersemangat karena siswa merasakan hal baru dalam belajar. 4) Biasanya siswa akan tertarik kepada hal-hal baru termaasuk dalam pembelajaran, hal ini yang dimanfaatkan oleh guru sebagai strategi untuk mengawali pembelajaran dengan model quantum teaching. 5) Ketika siswa mau diajak bekerja sama disitulah timbul rasa menghargai dan jalinan emosional yang akan membuat langkah pembelajaran berikutnya semakin mudah termasuk ketika siswa memahami materi yang disampaikan oleh guru. 6) Penghargaan yang diberikan oleh guru membuat siswa merasa dihargai. Jarang sekali siswa mendapatkan penghargaan atas apa yang telah mereka kerjakan. Siswa juga sangat jarang merayakan keberhasilan karena telah melaksanakan tugas dengan baik. Ketika siswa menjalani treatment dengan model pembelajaran Quantum Learning, prestasi baik berupa pendapat maupun pertanyaan sekecil apapun akan mendapatkan reward. Bahkan jika siswa mengalami kegagalanpun guru masih akan memberikan semangat. Kalau individumemiliki harapan yang tinggi terhadap dirinya, harga diri yang tinggi, dan keyakinan akan berhasil, maka individu tersebut akan memperoleh prestasi tinggi (DePorter \& Hernacki, 2000). 7) Penerapan sikap positif membuat siswa semakin menikmati belajar. Siswa semakin terpacu untuk berprestasi untuk mendapatkan penghargaan dan reward yang lebih banyak lagi. Hal ini lah yang menjadikan hasil belajar siswa semakin meningkat. Hal ini sesuai dengan kelebihan model quantum teaching. Model quantum teachingmempunyaibeberapakelebihanyaitu: 1) dapat memembimbing dan mengarahkan cara berpikir siswa; 2) berpusat terhadap apa yang dialami oleh siswa dalam proses belajarnya; 3) menumbuhkan dan menimbulkan keiinginan siswa untuk belajar; 4) menciptakan rasa kerjasama antar siswa; 5) menawarkan proses pembelajaran yang menyenangkan danmudah dipahami siswa; 6) menciptakan rasa percaya dirisiswa;7) menciptakanpembelajaran yang menyenangkan; 8) memotivasi siswa untuk terus berkembang; 9) siswa bebas berekspresi; 10) menumbuhkan rasa idealism, gairah dan cinta mengajar pada guru (Suryanti \& Yunianta, 2018).

Hasil penelitian ini didukung oleh beberapa penelitian sebelumnya yaitu Margadhyta, Suarjana, \& Agustiana (2013) dalam penelitiannya menunjukan terdapat perbedaan yang signifikan prestasi belajar IPA antara siswa yang dibelajarkan dengan menggunakan model pembelajaran quantum dan siswa yang dibelajarkan emnggunakan model pembelajaran konvensional.Hasil uji hipotesis kedua menunjukan adanya perbedaan sikap ilmiah siswa yang menggunakan model quantum learning mendapat hasil yang lebih tinggi. Dengan perolehan nilai rata-rata 75.43 sedangkan menggunakan model pembelajaran konvensional 72.34. Dengan demikian H0 ditolak dan H1 diterima. Penelitian yang dilakukan oleh Agus (2016) menyatakan bahwa 1) Penerapan model pembelajaran quantum teaching pada mata pelajaran IPA kelas IIID di SD YPS dilakukan dengan berdasar pada kerangka pembelajaran Tandur yaitu Tumbuhkan, Alami, Namai, Demonstrasikan, Ulangi dan Rayakan yang dijabarkan menjadi acuan untuk menyusun kegiatan pembelajaran. Pada setiap pertemuannya, guru melakukan evalusi terhadap proses pembelajaran sehingga aktivitas guru pada setiap pertemuan mengalami peningkatan. 2) Model pembelajaran quantum teaching berpengaruh positif terhadap hasil belajar IPA siswa kelas IIISD YPS Lawewu Kecamatan Nuha Kabupaten LuwuTimur. Hasil penelitian yang dilakukanoleh Wahyu, Putra, \& Suadnyana (2016) yang menyatakan bahwa model quantum teaching mampu meningkatkan hasil belajar Bahasa Indonesia (keterampilan menulis) siswa kelas IV SDN 5 BonganTabanan.

Berdasarkan hasil penelitian serta hasil penelitian sebelumnya dapat dikatakan bahwa model pembelajaran ini efektif digunakan pada siswa SD pada mata pelajaran IPA. Hal ini disebabkan karena model pembelajaran quantum teaching adalah salah satu model pembelajaran yang menciptakan suasana pembelajaran yang menyenangkan, mengaktifkan siswa, serta memotivasi siswa untuk menemukan sendiri pengetahuannya melalui kegitan pembelajaran TANDUR (tumbuhkan, alami, namai, demostrsikan, ulangi, danrasayakan). Kegitaniniakanmembuat belajar siswa lebih bermakna. Hal ini sesuai denganpendapat Astuti, Masykur, \& Pratiwi (2018) model quantum teaching tipe TANDUR menjadikan pembelajaran lebih bermakna bagi peserta didik karena peserta didik mengalami apa yang sedang dipelajari bukan sekedar melihat atau menghafal. Dengan pemberian pengalaman secara langsung akan membuat pengetahuan siswa akan lebih lama diingat. 


\section{Simpulan dan Saran}

Berdasarkan analisis data hasil penelitian dapat disimpulkan bahwa: 1) Peningkatan rata-rata siswa dengan menggunakan pembelajaran quantum teaching lebih baik dengan model pembelajaran konvensional. 2) pembelajaran quantum teaching dapat meningkatkan hasil belajar siswa 3) pembelajaran quantum teaching sangat membantu siswa memahami konsep IPA. Dari hasil penelitian ini disarankan kepada: 1) Pihak sekolah hendaknya bekerja sama dengan orang tua atau wali murid siswa dalam memberikan bimbingan kepada siswa untuk meningkatkan hasil belajar sehingga dapat mencapai hasil yang optimal. 2) Guru harus berani mencoba sesuatu yang baru yaitu hal yang dapat menumbuhkan motivasi siswa dalam belajar, khususnya dengan menerapkan model pembelajaran yang menarik dan sesuai dengan materi pelajaran dan karakter peserta didik. 2) Diharapkan semua peserta didik SD INPRES Kupa-Kupa menumbuhkan kesadaran dirinya bahwa mereka merupakan subyek belajar.

\section{Daftar Pustaka}

Astuti, T. P., Masykur, R., \& Pratiwi, D. D. (2018). Pengaruh model pembelajaran tandur terhadap kemampuan pemahaman konsep dan penalaran matematis peserta didik. Jurnal Pendidikan Matematika FKIP Univ. Muhammadiyah Metro, 7(2), 201-209.

Cahyaningrum, A. D., Yahya, \& Asyhari, A. (2019). Pengaruh model pembelajaran quantum teaching tipe tandur terhadap hasil belajar. Indonesian Journal of Science and Mathematics Education, 02(3), 372-379.

DePorter, B., \& dkk. (2014). Quantum Teaching (Mempraktikkan Quantum Learning di ruang-ruang kelas). Penerbit Kaifa.

DePorter, B., \& Hernacki, M. (2000). Quantum Learing Membiasakan Belajar Nyaman dan Menyenangkan. Penerbit Kaifa.

Fathurrahman, M. (2015). Model-Model Pembelajaran Inovatif. Ar-ruzz Media.

Fauzi, A. M., \& Noviartati, K. (2018). Pengaruh model pembelajaran quantum teaching tipe tandur ditinjau dari motivasi belajar siswa. Jurnal Elektronik Pembelajaran Matematika, 5(3), 240-248.

Isnaini, M., Wigati, I., \& Halimatussya'diyah. (2016). Pengaruh model pembelajaran quantum teaching dengan langkah-langkah tandur terhadap keterampilan proses belajar siswa materi sel Kelas XI di SMA Muhammadiyah 1 Palembang. Jurnal Bioilmi, 2(1), 16-29.

Kasmadi, H. (2001). Pengembangan pembelajaran dengan Pendekatan Model-Model Pengajaran. PT Prima NugrahaPratama.

Margadhyta, N. M. D., Suarjana, M., \& Agustiana, I. G. A. T. (2013). Pengaruh model pembelajaran quantum teaching gugus VI kecamatan buleleng.

Rachmawati, R. (2012). The Implementation Quantum Teaching Method of Graduate Through Up-Grade Hard Skill and Soft Skill. Procedia-Social and Behaviour Sciences, 57(2), 477-487.

Riyanto, Y. (2012). Paradigma Baru Pembelajaran. PT Rineka Cipta.

Rohimah, D. F., Suprapta, Bl., \& Agung, D. A. G. (2019). Pengaruh Model Pembelajaran Kuantum Tipe TANDUR terhadap Minat Belajar Siswa Kelas X. Jurnal Pendidikan, 4(9), 1229-1236.

Sagala, S. (2011). Konsep dan MaknaPembelajaran. Alfabeta.

Samatowa, U. (2010). Pembelajaran IPA di Sekolah Dasar. PT Indeks.

Sari, R. A. (2013). Inovasi Pembelajaran. Bumi Aksara.

Sugihartono. (2007). Psikologi Pendidikan. UNY Press.

Suryanti, W., \& Yunianta, T. N. H. (2018). Penerapan Model Pembelajaran Quantum Teaching Untuk Meningkatkan Hasil Belajar Matematika Materi Pecahan Pada Siswa Kelas VII SMP Negeri 3 Getasan. JMP Online, 2(1), 148-159.

Susanto, A. (2013). Teori Belajar \& Pembelajaran di Sekolah Dasar. Prenadamedia Group.

Trianto. (2010). Model Pembelajaran Terpadu: Konsep, Strategi, dan Implementasinya dalam Kurikulum Tingkat 
Satuan Pendidikan (KTSP). Bumi Aksara.

Wahyu, M., Putra, I. K., \& Suadnyana, I. N. (2016). Penerapan Model Quantum Teaching Untuk Meningkatkan Hasil Belajar Bahasa Indonesia (Keterampilan Menulis) Pada Siswa Kelas IV SD. E-Journal PGSD Universitas Pendidikan GaneshaJurusan PGSD, 4(1).

Wena, M. (2013). Strategi Pembelajaran Inovatif Kontemporer: Suatu Tinjauan Konseptual Operasional. Bumi Aksara.

Yahya, H. (2017). Pengaruh penerapan model pembelajaran quantum teaching terhadap hasil belajar biologi siswa sms islam terpadu al-fityan gowa. Jurnal Biotek, 5(1), 155-166.

Yanuarti, A., \& Sobandi, A. (2016). Upaya meningkatkan hasil belajar siswa melalui penerapan model pembelajaran quantum teaching. Jurnal Pendidikan Manajemen Perkantoran, 1(1), 11-18.

Yaseer, A., Sukestiyarno, \& Masrukan. (2014). Learning quantum teaching model with atong approach school program of integrated valid to improve character and critical thinking in probability material. International Conference on Mathematics, Science, and Education, 5(2), 85-91. 